\title{
Corporate Governance, Firm Size, and Earning Management: Evidence in Indonesia Stock Exchange
}

\author{
Dwi Lusi Tyasing Swastika \\ STIE Malangkuçeçwara, Malang
}

\begin{abstract}
Purpose -Thepurpose of this paper is to evaluate the impact of the corporate governance regulationsimplementation and firm size onthe earning management for food and beverages companies in Indonesian Stock Exchange.

Design/methodology/approach -The multiple regression is utilized to test this relationship at 95\% confidence.Corporate governance was proxied by board of director, audit quality, and board independence. Firm size was represented by natural logarithm of total assets. Earning management was measured by Jones model withdiscretionary accruals.

Findings - Using data from the year 2005 annual reports of 51 food and beverages listed companies, including the composite index, the results showed that twoof the corporate governance variables, namely board of director and audit quality, as well as firm size are statistically significant in explaining earning management measured bydiscretionary accruals.

Research limitations/implications - The regulations on corporate governance were implementedin 2005, but not all of food and beverages listed companies implemented the regulations in 2005.

Practical implications - An implication of this finding is that regulatory efforts initiated after the 1997 financial crisis to enhance corporate transparency and accountability did not appear to result on better corporate performance.
\end{abstract}

Originality/value - This is one of the few studies which investigates the impact of regulatory actionson corporate governance on earning management immediately after its implementation.

Keywords Corporate governance, Firm size, Earning Management

Paper type Research paper

\section{Introduction}

Agency conflicts are expected to be higher in widely heldcompanies due to divergence of interest among contracting parties (Jensen andMeckling, 1976). One such conflict may arise between inside ownermanagers andoutside minority shareholders. Fama and Jensen (1983) argue that the existence ofindependent directors would result in a more effective monitoring of the board and limitmanagerial opportunism. That is because independent directors are supposed to lookafter the interests of outside minority shareholders. Thus, to reduce agency conflicts,independent directors can be appointed to the board. Following this line of argument, ifindependent directors succeed in discharging their monitoring role and ensuring that theboard makes decision in the best interests of all shareholders, opportunistic behaviorcould be avoided; hence, company performance should improve.

Another characteristic that is seen to influence a board'sability to monitor is board size. Boards can become lesseffective in controlling management as board size increasesdue to problems of coordination and communication(Jensen, 1993). Nevertheless, results regarding the effect ofboard size on earnings management are not so obvious.Some authors find a positive association between board sizeand earnings management (Chin, Firth, and Rui [2006] for313 firms in Hong Kong), and others a negative relation(Xie, Wallace, and Dadalt [2003] for a sample of 110 USfirms) or even no relation (Bradbury et al. [2006] for firms inMalaysia and Singapore).

Another important characteristic of boards is whetherthe roles of the chairperson and the chief executive officer (CEO)are vested in different people. Corporate governance guidelinesassume that a board is less able to perform a monitoringrole when the CEO is also the chairperson of the board.CEO duality indicates that less control is likely to be exercisedover management's activities and behavior. Empiricalevidence on the association between CEO duality andopportunistic managerial behavior, however, seems not tosupport this theory since most authors do not find any significantrelation (Bugshan, 2005; Cornett, Marcus, Saunders,\&Tehranian, 2006; Davidson et al., 2005).In monitoring the financial discretion of management, it isthe audit committee that is likely to provide shareholderswith the most protection in maintaining the credibility of afirm's financial statements. Thus, independent audit committeescan potentially improve the quality and credibility offinancial reporting. The best practice standard establishes 100 percent of independent directors; and, though in moststudies the percentage of independent directors is higherthan 50 percent, it does not reach 100 
percent. On the contrary, inthe samples of Yang and Krishnan (2005) for US andBugshan (2005) for Australia there are 82 percent of independentdirectors in the audit committee, in García-Osmaand Gill de Albornoz (2007) for Spain the mean is 56 percent.Nevertheless, results in this area are also conflicting. WhileKlein (2002) reports a negative relation between earningsmanagement and audit committee independence, otherauthors find no association between both variables (Yangand Krishnan [2005] in the USA, and García-Osma and GilldeAlbornoz [2007] in Spain).

\section{Development of Hypotheses Firm Size}

Firm Size is defined as the nature $\log (\ln )$ of total assets (Chen et. Al., 2005; Ghazali, 2010; Hasanand Ahmed, 2012). It is used in this study to control the likely impact of firm size on the discretionary accruals of the sample firms. It is argued that the larger firm sizemeans the higher the expected agency problem that the firm is likely to experience (Abed et. Al., 2012);furthermore, given the fact that large firms have more resources and earn higher profit, Grey and Clarke (2004) note that those firms are more likely to avoid managing earnings through discretionary accruals. Quite a number of studies control for firm size including Zhu and Tian (2009) and Shehu (2011).

The effect of firm size on earnings management is controversial (Kouki et al, 2011). We have two opposite point of views:(1) the first defended byLennox (1999), Gore et al.(2001), Klein (2002), Xie et al. (2003), Abdul Rahman and Ali (2006) advanced a negative relationship; larger firms with sophisticated internal control systems, more competent auditors(Big5) and have better reputation; are more able to avoid earnings management. This support the idea that smaller companies are subject to less control fromauthority and therefore, managers are more likely engage in earnings management activities (Abed et al, 2012); (2) the opposite view suggests a positive relation between size and earnings management; larger companies with more capital market pressure, morebargaining power; are more likely to manage earnings than are their counterparts of small firms(Moses, 1987; Myers and Skinner, 2000; Nelson et al, 2002). A negative association between firm size and earning management is hypothesized:

$\mathbf{H}_{1}$. There is a significant negative between firm size and earning management.

\section{Corporate Governance}

Corporate governance is represented by board of director, audit quality, and board independence.

Board of Director.Boards of directors can play a significant role in control inagency problems (Garcia-Meca and Sances-Balesta, 2009). From an agency perspective, the ability ofthe board to act as an effective monitoring mechanismdepends on its independence of management (Beasley, 1996;Dechow et al., 1996). According to Fama and Jensen (1983),independent directors on boards make boards more effectivein monitoring managers and exercising control on behalf ofshareholders. Dalton et al. (1999) showed that larger board members provide more advantages for their companies throughsharing alternative experience which might decrease the incidence of earnings management.Previous studies have used board size as a determinant of earnings management, but the influence of board of director hasreceived mixed results in previous studies. Abdul Rahman and Ali (2006) found a positive relationbetween earnings management and board of director. However, Xie et al. (2003) and Peasnell et al. (2005) found anegative association between earnings management and board of director. Interestingly, Abbott et al. (2000) found norelation between quality of earnings and board of director. Thus, based on agency theory, it can be hypothesized that:

$\mathbf{H}_{2}$ : There is a significant positive relationship between board of director and earnings management.

Board Independence. The effect of board independence onearnings management is not so specific in the description ofboard independence, which is usually referred to nonexecutivedirectors. This limits the analysis of board independenceto the category of non-executive directors, and restrictsthe possibility of a deeper examination of how these differentroles may constrain managerial discretional behavior (Garcia-Meca and Sances-Ballesta, 2009).Results on the association between earnings managementand board independence in previous literature are conflicting. While Davidson, Goodwin-Stewart, and Kent (2005) findempirical support for the effective role of independentdirectors in constraining earnings management in Australianfirms;Bradbury, Mark, and Tan (2006) in Singapore fail tofind any association between earnings management andboard independence. Board independence will be moreaware of their responsibilities and would discharge those responsibilities moreeffectively. It is hypothesized that the higher the proportion of board independence onthe board the better will not be the earning management:

$\mathbf{H}_{3}$. There is a significant negative between board independence and earnings management.

Audit Quality. Audit quality on audit committee plays an important role in monitoring management to protect shareholders' interest (Hasan and Ahmed, 2012). The code of best governance practice in Nigeria requires that 
the committee should be largely independent, highly competent and possess high level of integrity. It is responsible for the review of the integrity of financial reporting and oversees the independence and objectivity of the external auditors(Hasan and Ahmed, 2012). Audit committee has been explored in prior literature and how it relates to earnings management using various constructs of audit committee effectiveness such as size of the board (Yermack, 1996: Xie et al., 2001), composition and independence (Klein, 2002), audit committee meetings (Beasley et al., 2000), financial expertise of committee members (Kalbers and Fogarty, 1993), and financial motivation of independent directors (Chtourou, Bedard and Corteau., 2001). In the existing literature, (Hassan, 2011) observed that more attention has been given to financial expertise as a construct of board competence. This, he observed, could be misleading as accounting expertise is much more relevant to the board members in the discharge of their duties as a monitoring mechanism.

Audit quality measured with dummy variable, which thecompanies are audited by Big 4 (public accountantoffice or large KAP) then it is thehigh-quality audits and if audited by non Big4 (small KAP), it is the low audit quality (Sirat, 2012). KAP Big 4 in Indonesia (Susiana and Herawaty, 2007) are (1) Price Water House Coopers (PWC), with Indonesian partner are HaryantoSaharidanRekan; (2) Deloitte Touche Tohmatsu, with Indonesian partner areOsman, Ramli, SatriodanRekan; (3) Klynveld Peat Marwick Goerdeler (KPMG) International, with Indonesian partner areSiddhartaand Widjaja; (4) Ernst and Young (EY), with Indonesian partner arePrasetio, SarwokodanSandjaja.Thus, based on KAP Big 4, it can be hypothesized that:

$\mathbf{H}_{4}$ : There is a significant negativerelationship between board of directorand earnings management.

\section{Dependent Variable \\ Earning Management}

Earning management in this study is measured using accounting accruals approach. Accruals are likely to capture evidence of earnings management because theyreflect managers'accounting estimation and accounting choices (Chen et al, 2005). Dechow et al. (1995)provide evidence that the modified Jones model is the most powerful model to detectearnings management among the alternative models to measure unexpected accruals.Therefore, a cross-sectional modified Jones model is used. However, a drawback ofthe modified Jones model commonly used to measure earnings management is that itdoes so with measurement error (Kothari et al. 2005). To address this concern, weinclude prior period ROA measured as net income divided by total assets as aperformance measure in the model.The discretionary accruals are estimated as follows. Total accruals are measuredas net income minus cash flows from operation.

Then discretionary accruals, a proxy for earnings management, are estimated by subtracting nondiscretionary accruals from total accruals, where all accrual variablesare scaled by lagged total assets to control for potential scale bias(Chen et al, 2005). Normal levels ofworking capital accruals related to sales are controlled through the changes in revenueadjusted for changes in accounts receivable.

$$
\mathbf{T A}_{\mathrm{i}, \mathrm{t}}=\mathrm{NI}_{\mathrm{i}, \mathrm{t}}-\mathrm{CFO}_{\mathrm{i}, \mathrm{t}}
$$

Normal levels of depreciation expenseand related deferred tax accruals are controlled through the property, plant, andequipment. Lagged $\mathrm{ROA}_{\mathrm{i}, \mathrm{t}}$ is added as suggested by Kothari et al. (2005). Finally, theresidual ( $\left.\varepsilon i t\right)$ from the regression is the discretionary accruals(Chen et al, 2005).

$$
\begin{aligned}
& \frac{T A_{i, t}}{A_{i, t-1}}=\alpha_{1}\left(\frac{1}{A_{i, t-1}}\right)+\alpha_{2}\left(\frac{\Delta R E V_{i, t}-\Delta R E C_{i, t}}{A_{i, t-1}}\right)+\alpha_{3}\left(\frac{P P E_{i, t}}{A_{i, t-1}}\right)+\alpha_{4} R O A_{o, t-1}+\varepsilon_{i, t} \\
& \frac{N D A_{i, t}}{A_{i, t-1}}=\hat{\alpha}_{1}\left(\frac{1}{A_{i, t-1}}\right)+\hat{\alpha}_{2}\left[\frac{\left(\Delta R E V_{i, t}-\Delta R E C_{i, t}\right)}{A_{i, t-1}}\right]+\hat{\alpha}_{3}\left(\frac{P P E_{i, t}}{A_{i, t-1}}\right)+\hat{\alpha}_{4} R O A_{i, t-1} \\
& \frac{D A_{i, t}}{A_{i, t-1}}=\frac{T A_{i, t}}{A_{i, t-1}}-\left\{\hat{\alpha}_{1}\left(\frac{1}{A_{i, t-1}}\right)+\hat{\alpha}_{2}\left[\frac{\left(\Delta R E V_{i, t}-\Delta R E C_{i, t}\right)}{A_{i, t-1}}\right]+\hat{\alpha}_{3}\left(\frac{P P E_{i, t}}{A_{i, t-1}}\right)+\hat{\alpha}_{4} R O A_{i, t-1}\right\}
\end{aligned}
$$

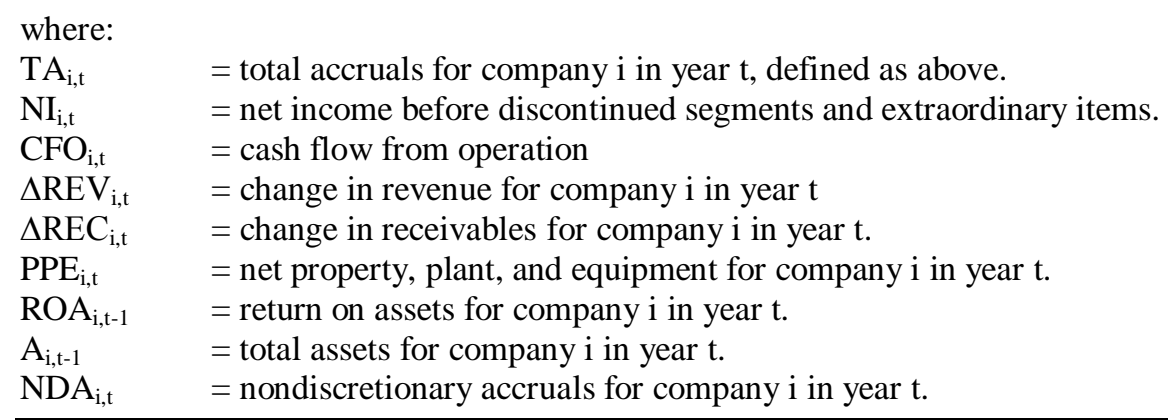


$\mathrm{DA}_{\mathrm{i}, \mathrm{t}}=$ discretionary accruals for company $\mathrm{i}$ in year $\mathrm{t}$.

$\varepsilon_{i, t} \quad=$ residual for company $\mathrm{i}$ in year $\mathrm{t}$.

This study is subject to a number of limitations. First, our results demonstrate anassociation, instead of causation, between corporate governance characteristics andthe likelihood of earnings management. Second, we use the popular cross-sectionalmodified Jones model to estimate discretionary accruals. We incorporate lagged ROAas an additional factor to control for firm performance(Chen et al, 2005). Due to data limitations, we donot use performance-matched discretionary accruals as suggested by Kothari et al.(2005). Therefore, our results may still be subject to the potential concerns ofmeasurement error. Third, we only include the corporate governance characteristics(i.e., independence and financial expertise) required by the Principles, and governanceexpertise and voluntary formation of independent directors and supervisors to test ourhypotheses(Chen et al, 2005).

\section{Research Method}

The data for this study were collected from 2005until 2007 annual reports of food and beverages listed companies.The annual reports were downloaded from the Indonesia Stocks Exchange's official website (www.idx.or.id).Companies chosen for analysis were those included in the composite index.Companies included in the composite index are generally actively traded and large insize. Given their high volume of trade, it is thus appropriate to assume that these are thecompanies that more readily attract the interest of investors. Consequently, it may beexpected that these companies would apply good corporate governance practices. Withthe exception of 51 companies, all other 57 food and beverages listed companies in the composite indexwere included in the analysis.

The multiple regression was used to analyzethe impact of the implementation of corporate governance regulations and firm size on earning management. Theformulation of the multiple regression modelsis as the following:

DisAcc $=\beta_{0}+\beta_{1}$ FirSiz $+\beta_{2}$ BoaDir $+\beta_{3}$ BoaInd $+\beta_{4}$ AudQua $+\varepsilon$

Table 1 shows operationof all variables included in the analysis.

Table 1. Variable included in the regression analysis

\begin{tabular}{ll}
\hline Variable & Definition \\
\hline DisAcc & Earning management measured by discretionary accruals. \\
$\beta_{0} \ldots . . . \beta_{4}$ & Regression coefficient \\
FirSiz & Firm Size measured by natural logarithm of total assets \\
BoaDir & Board of Directoris the number of directors on the boards. \\
BoaInd & Board Independenceis number of independent commission. \\
AudQua & Audit Quality, is dummy variable, 1 if audited by KAP Big 4; 0 otherwise \\
\hline
\end{tabular}

\section{Findings and Analysis}

\section{Descriptive statistics}

Table 2 shows descriptive statistics of all variables. Panel (a) of Table 1shows that discretionary accruals which shows between -0.45 and 0.34 . This is show that food and beverages listed company make earning management on their operation. Firm size which shows between 20.99 and 30.42, that the larger firm size the higher the expected agency problem that the firm is likely to experience. Board of director in the companies investigated was as high as10 with a mean of 4.96 (5). Directors on boards make boards more effectivein monitoring managers and exercising control on behalf ofshareholders. Board independence was as high as 0.57 with a mean of 0.33 . The higher the proportion of board independence onthe board the better will not be the earning management.

Panel (b) of Table 1 shows that 51 percent of the sample companies audited byKAP non Big4. Thecompanies are audited by KAP Big4 is thehigh-quality audits and if audited by KAP non Big4 is the low audit quality.

Table 2. Descriptive Statistics of Variables

\begin{tabular}{lllll}
\hline $\begin{array}{l}\text { Panel } \boldsymbol{a} \text {. } \\
\text { Continuous Variabels }\end{array}$ & & & & \\
\hline Variables & Label & Min & Max & Mean \\
\hline Discretionary Accruals & DisAcc & -0.45 & 0.34 & -0.16 \\
Firm Size & FirSiz & 20.99 & 30.42 & 27.23 \\
Board of Director & BoaDir & 3 & 10 & 4.96 \\
Board Independence & BoaInd & 0.20 & 0.57 & 0.33 \\
\hline
\end{tabular}




\begin{tabular}{|c|c|c|c|}
\hline $\begin{array}{l}\text { Panel b. } \\
\text { Categorical Variables }\end{array}$ & & & \\
\hline Audit Quality & AudQua & $\begin{array}{l}1=\text { audited byKAP } \\
\text { Big } 4 \\
25(49 \%)\end{array}$ & $\begin{array}{l}0=\text { audited by KAP } \\
\text { non Big } 4 \\
26(51 \%)\end{array}$ \\
\hline
\end{tabular}

To determine the association between the implementation of corporate governance regulations and firm size on earning management, a multiple regression analysisemploying four independent variables was carried out.Table 3 shows the results of the regression analysis. It can be seen from Table 3 that the regression model which incorporates four independent variables results in an adjusted $\mathrm{R}^{2}$ of 25.4 percent. This means that the four variables tested were ableto explain 25.4 percent of the variation in earning management among Indonesia food and beverages listedcompanies investigated in this study. The results showed that two of the corporate governance variables, namely board of director and audit quality, with firm size wasstatistically significant in explaining earning management measured by discretionary accruals. Corporate governance namely board of director were positive, and audit quality were negative associated with earning management. Firm size was negative associated with earning management.

Board of director was statistically significantat the 1 percent level. Consistent with the expectation, companies with a larger proportionof board director were found to be more make operation with earning management. Firm size and audit qualitywere statistically significant at the 10 percent level. As hypothesized, companies in whichthe larger companies and more qualified auditor tend to obey earning management.

Table 3. Standard Multiple Regression Result

\begin{tabular}{|c|c|c|c|c|c|}
\hline Adjusted $R^{2}$ & 25,4 & & & & \\
\hline$F$-statistics & 5,253 & & & & \\
\hline Significance & 0,001 & & & & \\
\hline \multicolumn{6}{|l|}{ Variables } \\
\hline & $\beta$ & t-value & Significance & Tolerance & $V I F$ \\
\hline Constant & 0,489 & 1,454 & 0,153 & & \\
\hline FirSiz & $-2,65 \mathrm{E}-02$ & $-2,102$ & $0,041 *$ & 0,872 & 1,146 \\
\hline BoaDir & 4,707E-02 & 4,440 & $0,000 * *$ & 0,759 & 1,317 \\
\hline AudQua & $-9,53 \mathrm{E}-02$ & $-2,059$ & $0,045^{*}$ & 0,643 & 1,556 \\
\hline BoaInd & $-0,357$ & $-1,151$ & 0,256 & 0,733 & 1,364 \\
\hline
\end{tabular}

Note: Coefficient are shown as significant at: $* 5$ or $* * 1$ percent level

\section{Conclusions And Suggestions For Future Research}

This paper has examined the impact of corporate governance on corporate performance.The results showed weak evidence to indicate that companies which adopted goodgovernance practices performed better than others. None of the corporate governancevariables were statistically significant in explaining corporate performance. This findingcould be partially due to the time period under examination. The regulations on corporategovernance were implemented in 2001; perhaps it was too early to analyze results for thefinancial year 2001 as regulatory changes may take a few years before they can beexpected to show positive or intended results. Nonetheless, one may still question therelevance and effectiveness of the Code as even though the regulations cameabout in 2001, the market knew about the efforts long before the introduction, as evidenced in the 1998survey. A possible explanation for this finding could be that perhaps the Code which isbased on the Hampel Report in the UK is not suitable in the Malaysian context due todifferent political and cultural factors affecting business environment. Another possiblefactor influencing corporate governance effectiveness could be the legal environment of acountry. Malaysia has a low litigious environment as opposed to the USA and UK whereshareholder protection is very good (La Porta et al., 1999). Thatmay have some bearing onincentives to comply with regulatory requirements.

Future research on corporate governance and corporate performance could considerthe above factors when planning their research design. Analyzing data which are not tooclose to the year of implementation of corporate governance guidelines may providebetter insight into the impact of corporate governance on corporate performance.Additionally, a different methodology such as interviewing market participants can beundertaken to gather industry views on issues related to corporate governance.Interviews may shed some light on the effectiveness of board independence. Findingsfrom the interviews could provide fruitful suggestions on howbest to design a corporategovernance regime for each/different business setting(s) to ensure realization oflong-term stakeholders' value. 


\section{References}

[1]. Abed, Suzan; Al-Attar, Ali; Suwaidan, Mishiel(2012) "Corporate Governance and Earnings Management: Jordanian Evidence". International Business Research Vol. 5, No. 1; January.

[2]. Al-Fayoumi, Nedal; Abuzayed, Bana; Alexander, David (2010) “Ownership Structure and Earnings Management inEmerging Markets: The Case of Jordan”. International Research Journal of Finance and Economics, Issue 38.

[3]. Chen, Ken Y.; Elder, Randal J.; Hsieh, Yung-Ming. (2005)Corporate Governance and Earnings Management: The Implications ofCorporate Governance Best-Practice Principles for Taiwanese Listed Companies, December.

[4]. Chtourou, SondaMarrakchi; Bédard, Jean; Courteau, Lucie (2001). Corporate Governance and Earnings Management. Université Laval, Canada.

[5]. Cornett, Marcia Millon; McNutt, Jamie John; Tehranian, Hassan (2009) "Corporate Governance And Earnings Management At Large U.S. BankHolding Companies”, Journal of Corporate Finance 15, pp 412-430.

[6]. Emma García-Meca, Emma and Sánchez-Ballesta, Juan P. (2009) "Corporate Governance and EarningsManagement: A MetaAnalysis", Corporate Governance: An International Review, 17(5), pp 594-610.

[7]. Ghazali, NazliAnumMohd. (2010) "Ownership Structure, Corporate Governance and Corporate Performance in Malaysia". International Journal of Commerce and Management, Vol. 20, No. 2, pp 109-119.

[8]. Hassan, Shehu Usman; Ahmed, Abubakar (2012) "Corporate Governance, Earnings Management and Financial Performance: A Case of Nigerian Manufacturing Firms". American International Journal of Contemporary Research Vol. 2 No. 7, July.

[9]. Kouki, Mondher; Elkhaldi, Abderrazek; Atri, Hanen; Souid, Slim(2011) "Does Corporate Governance Constrain Earnings Management?Evidence from U.S. Firms", European Journal of Economics, Finance and Administrative Sciences,Issue 35.

[10]. Meeampol, Sasivimol; Rueangsuwan, Sarayut; Jaithat, Pairin(2012) "An Empirical Analysis Of The Relation BetweenCorporate Governance And Earnings Management:Case Study Of Thailand”. Management, Knowledge and Learning. International Conference.

[11]. Rezaei, Farzin (2012) "Efficient or Opportunistic Earnings Management with Regards to the Role ofFirm Size and Corporate Governance Practices". Interdisciplinary Journal of Contemporary Research In Business, January, Vol 3, No 9.

[12]. Sirat, Hadi (2012) "Corporate Governance Practices, Share OwnershipStructure, and Size on Earning Management". Journal of Economics, Business, and Accountancy Ventura Volume 15, No. 1, April, pp 145 - 156.

[13]. Wang, Juo-Lien; Sheu, Her-Jiun; Chung, Huimin (2011)“Corporate Governance Reform and Earnings Management”,Investment Management and Financial Innovations, Volume 8,Issue 4. 